Www.jmscr.igmpublication.org

Impact Factor (SJIF): 6.379

Index Copernicus Value: 79.54

ISSN (e)-2347-176x ISSN (p) 2455-0450

crossrefDOI: https://dx.doi.org/10.18535/jmscr/v6i8.111

Journal Of Medical Science And Clinical Research

\title{
Fibrous Dysplasia of Maxilla - Surgical Sculpting for Aesthetics
}

\author{
Authors \\ Vellavedu Umapathy Shanmugam, Yoganathan Gnanavelu, Ruta Shanmugam, \\ Prem Nivas, Iyaswamy Bharat \\ Department of Otorhinolaryngology, Rajah Muthiah Medical College, Chidambaram \\ Email: Ygnanavelu123@gmail.com
}

\begin{abstract}
Fibrous dysplasia is a developmental deformity of bone in which there is an abnormal proliferation of bone forming mesenchyme. It is a disease of unknown etiology and diverse histopathology. The disease can involve single bone (mono-ostotic) or many bones (poly-ostotic). In the head and neck region, Mono-ostotic forms frequently involve the maxilla and mandible. We are presenting one such case which presented to our department which was surgically sculpted by the Caldwell Luc approach

Keywords: Fibrous dysplasia, Maxilla, Fibro Osseous lesion.
\end{abstract}

\section{Introduction}

Fibrous dysplasia is a benign disease which is characterized by replacement of normal bone by cellular fibrous connective tissue, containing irregular trabecules of immature, nonlamellar, metaplastic bone. It is a condition where the primary fibrous tissue gradually expands and replaces the bone ${ }^{(1)}$. The disease usually develops at an early age, keeps progressing through the childhood and becomes static at adulthood. The disease is diagnosed by the second decade of life ${ }^{(2)}$.

\section{Case Report}

A 19 year old girl presented to our outpatient department with complaints of a gradually progressive swelling of the left cheek of 4 years duration. The swelling was associated with pain for the past 1 year. On inspection there was a diffuse homogenous swelling over the left cheek which on palpation was hard and had a smooth surface. The margins could not be well made out. Skin over the swelling was normal.

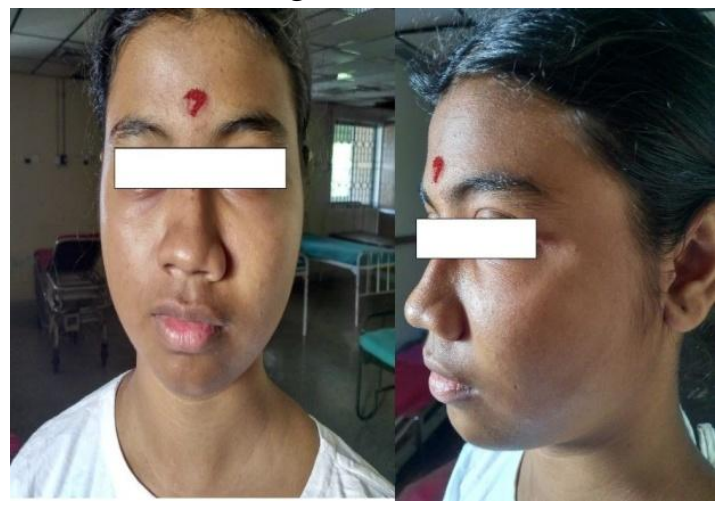

Fig. 1 Preoperative front and side facial profiles of the patient

Computed tomography imaging of the paranasal sinuses revealed that the anterior wall of left maxillary sinus had a well circumscribed expansive ground glass density lesion with a surrounding thin sclerotic bone having onion peel-like appearance suggestive of fibrous dysplasia of left maxilla. 


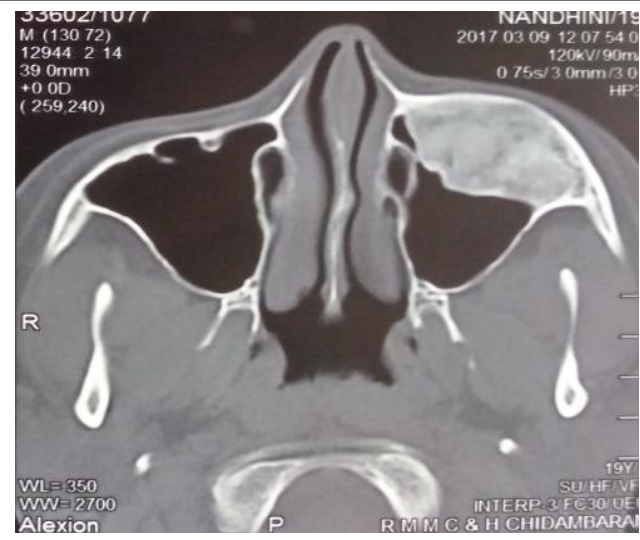

Fig. 2 computed tomographic image showing the involvement of left maxillary sinus

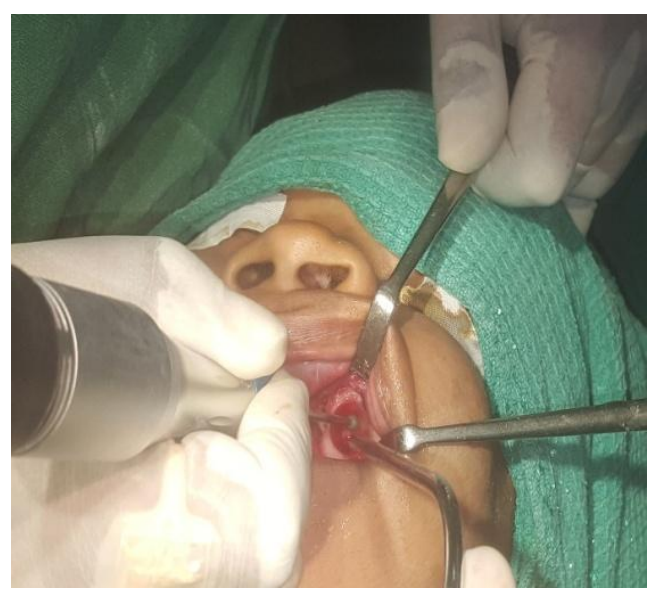

Fig. 3 drilling of anterior wall of left maxillary sinus to remove the diseased bone with handheld micromotor.

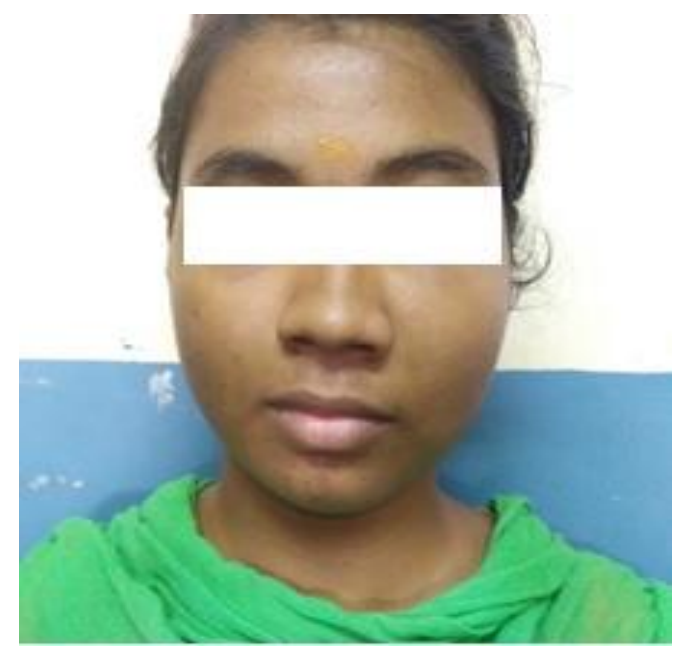

Fig.4 post operative facial profile of the patient

Excision of the diffuse localised bony hard swelling was planned through Caldwell Luc approach. Incision was made 2 to $3 \mathrm{~mm}$ above the gingivolabial sulcus on the left side and mucosal flap was elevated. Anterior wall of the left maxillary sinus was identified. Diseased bone along the anterior wall of maxillary sinus was drilled and removed up to a point where both sides of the face were symmetrical in appearance. The diseased anterior wall of left maxillary sinus had a maximum thickness up to 3 centimetres. Drainage of maxillary sinus into nasal cavity was facilitated by middle meatal antrostomy. Maxillary sinus and nose were packed with betadine soaked gauze. Sublabial incision was sutured. Specimen was sent for histopathological examination which showed irregular trabeculae of bone matrix and fibrous tissue mixed with normal bone, confirming the diagnosis of fibrous dysplasia. The patient was followed up at the end of 2 weeks, 4 weeks and then for every month until 6 months. Post operative period was uneventful.

\section{Discussion}

Fibro-osseous lesions (FOLs) include a group of processes which are characterized by replacement of the normal bone by fibrous tissue. This fibrous tissue contains mineralised, newly formed material called cementoid or osteoid due to their similarity to normal bone or cementum. The Fibro-osseous lesions can be classified as fibrous dysplasia, cementoosseous dysplasia and ossifying fibroma $^{(3)}$

Fibrous dysplasia is a benign fibro-osseouslesion in which a normal bone is replaced by cellularfibrous tissue containing trabeculae composed of non-lamellar bone.

Fibrous dysplasia was reported initially in 1981 by Von Recklinghausen and he coined the term Osteitis Fibrosa Generalisata ${ }^{(4,5)}$. In 1938, Lichtenstein and Jaffe (first) coined the term Fibrous Dysplasia ${ }^{(4,6)}$. Mc Cune and Albright et al explained the triad of polyostotic fibrous dysplasia, precociouspuberty, and areas of cutaneous pigmentation (cafe'-au-lait spots) as the McCune-Albright syndrome ${ }^{(4)}$.

Fibrous dysplasia can clinically present as any of the 3 types 1.involving a single site: mono-ostotic 2. involving more than one bony site:poly-ostotic 3.poly-ostotic form with extra-skeletal 
abnormalities. A mutation in stimulatory $\mathrm{G}_{\mathrm{s}}$ alpha $\mathrm{G}$ protein is found in all these 3 types. Out of these, mono-ostotic form is the commonest one accounting for seventy percentage of cases. The mono-ostotic form of the disease is commoner among females and whites.

The signs and symptoms are closely related to their evolution and the bones involved. Skull involvement is seen in $15 \%$ of cases of fibrous dysplasia. In the skull, every third case involve either the mandible or maxilla. In $75 \%$ of the cases, visible swelling, deformity or compression of functionally important structures will be the presenting initial complaint. Bone pain is an uncommon presentation in the initial stages. The other symptoms reported by the patients are (throbbing pain) or discomfort, diplopia, visual disturbances orvisual loss and nasal obstruction ${ }^{(5)}$. Its slow growth can cause several complications such as recurrent headache, nasal obstruction, chronic sinusitis, facial asymmetry and dental malocclusion. Cranial nerve involvement due to narrowing of foramina is very uncommon but can be found, causing paralysis ${ }^{(7)}$.

The radiographic appearance depends on its histologic structure. If there is more of the osseous elements, the lesion will appear more radio opaque. A mixture of bony and fibrous elements will give a ground glass appearance, while increased fibrous elements will produce a radiolucent picture. In the younger patients, the lesion appears as a homogenous density with a somewhat stippled appearance, but in older age patients, lesion is radio opaque due to more bone content. ${ }^{(8)}$

The recommended treatment options for fibrous dysplasia are observation, medical and surgical therapy. Observation is the mainstay of treatment modality for small asymptomatic lesions. Large lesions are corrected by surgery, directed at correcting (remodelling) or preventing functional deficits and achieving normal facial aesthetics. ${ }^{(9)}$

The patient discussed in this article had swelling in the left side of the face which was surgically sculpted and remodelled.

\section{Conclusion}

Monoostotic type of fibrous dysplasia of head and neck region most commonly involves maxilla and mandible. Small and asymptomatic lesions can be observed. Large and symptomatic lesions require surgical remodelling.

\section{References}

1. OZEK, C., GUNDOGAN, H., BILKAY, U., TOKAT, C., GURLER, T. and SONGUR, E. Craniomaxillofacial fibrous dysplasia. The Journal of Craniofacial Surgery, 2002, vol. 13, n. 3, p. 382-389.

2. Scott-Brown, W. and Gleeson, $M$. (2008). Scott-Brown's

Otorhinolaryngology, head and neck surgery. 7th ed. [England]: Edward Arnold, pp.1522-23.

3. BARNES, EL., EVESON, JW., REICHART, P. and SIDRANSKY, D. Pathology and genetics of head and neck tumours. Lyon: IARC Press, 2005. 430 P.

4. Ricalde P, Horswell BB. Craniofacial fibrous dysplasia of the Fronto- Orbital Region: A Case series and Literature. J Oral MaxillofacSurg2001; 59:157-168.

5. SANTOS, JN., VIEIRA, TSLS., GÓIS FILHO, DM., VASCONCELOS, SJA. and AZVEDO, RA. Displasiafibrosa: osteoplastia com acesso Weber-Ferguson: relato de caso. Revista de Cirurgia $e$ TraumatologiaBuco-Maxilo-Facial, 2010, vol. 10, n. 1, p. 73-80.

6. Sharma RS, Mahapatra AK, Pawar SJ, et al Symptomatic cranial fibrous dysplasia: Clinico-radiological analysis in a series of 8 operative cases with follow-up results. $J$ ClinNeurosci2002; 9(4):381-390.

7. LISLE, DA., MONSOUR, PA. and MASKIELL, CD. Imaging of craniofacial fibrous dysplasia. Journal of Medical Imaging and Radiation Oncology, 2008, vol. 52, n. 4, p. 325-332. 
8. Williams AQ, Browne RM, Akinosi JO. Journal of National Medical Association May 1974; 66(3):185-191.

9. Menon S, Venkatswamy S, Ramu V, Banu K, Ehtaih S, Kashyap VM. Craniofacial fibrous dysplasia: Surgery and literature review. Ann Maxillofac Surg 2013; 3:6671. 